\title{
Cognitieve beperkingen herkennen na COVID-19
}

Marcel Slockers, Tessa Magnée

We weten dat een acute, ernstige somatische aandoening zoals een longontsteking, een enorme impact kan hebben op het lichamelijk en cognitief functioneren. Ook maanden nadat patiënten beter zijn verklaard. Over de impact van COVID-19 op het cognitief functioneren is nog weinig bekend. De schaarse wetenschappelijke literatuur geeft aanwijzingen dat een ernstige infectie (met ic-opname) mogelijk ook kan leiden tot neurologische schade en verminderd cognitief functioneren. Niet alleen patiënten die op de ic-afdeling hebben gelegen lijken last te hebben van cognitieve klachten, maar ook patiënten met een minder ernstige infectie die op een andere afdeling in het ziekenhuis hebben gelegen of thuis zijn hersteld. We willen huisartsen aanmoedigen het cognitief functioneren van alle patiënten met COVID-19 te monitoren en deze patiënten bij het herstel advies te geven en te ondersteunen.

\section{COGNITIEVE RESTKLACHTEN}

We weten nog niet veel over restklachten na een doorgemaakte COVID-19-infectie. Deze patiënten kunnen last hebben van moeheidsklachten, benauwdheid, hoesten, en verlies van reuk en smaak. Huisartsen spelen een belangrijke rol bij de nazorg voor deze groep patiënten, waarvan de omvang nog onbekend is. Uit observaties in de huisartsenpraktijk blijkt dat ze ook met cognitieve klachten kunnen kampen. Het betreft een breed scala aan moeilijk te duiden verschijnselen, zoals warrig zijn, zaken moeilijk onthouden, minder zelfredzaamheid en concentratieproblemen.

Wat is er bekend uit de literatuur?

Tijdens een ernstig ziektebeeld kan het cognitief functioneren aangetast worden, bijvoorbeeld bij een delier. ${ }^{1}$ Ook nadat patiënten hersteld verklaard zijn van een delier, kunnen ze beperkingen in het cognitief functioneren houden. ${ }^{1}$

Over de impact van een COVID-19-infectie op het cognitief functioneren van beter verklaarde patiënten is nog niet veel bekend. Daarom voerden we op 1 augustus 2020 een oriënterende zoekopdracht uit in PubMed [kader].

Het gepubliceerde onderzoek over de cognitieve gevolgen van COVID-19 richt zich voornamelijk op patiënten die een ernstige infectie hebben gehad en hiervoor op de ic-afdeling hebben gelegen. Italiaanse patiënten die COVID-19 hebben

\begin{abstract}
CASUS
Een 64-jarige vrouw komt onaangekondigd op de praktijk omdat ze zich ziek voelt en een droge hoest heeft. Ze is benauwd en heeft smaakverlies. Behalve een goed ingestelde, oraal met metformine gereguleerde diabetes en overgewicht is ze verder gezond. Ze heeft geen psychische klachten in de voorgeschiedenis. Ze heeft een vmbo-opleidingsniveau en woont in een wijk met een lage SES. Haar ademhaling is versneld, ze heeft een temperatuur van $36,9^{\circ} \mathrm{C}$ en een saturatie van $88 \%$. Haar huisarts verwijst haar naar de longarts. Een COVID-19-test is positief en een CT-scan laat matglasafwijkingen zien. Ze krijgt zuurstof op de COVID-afdeling - ic-opname is niet nodig. $\mathrm{Na}$ 4 dagen is ze voldoende hersteld om naar huis te kunnen. Tijdens een volgend bezoek aan haar huisarts vertelt ze een warrig hoofd te hebben en veel te vergeten. Zaken regelen lukt slecht en ze kan zich tijdens een gesprek niet concentreren.

De partner van de patiënte krijgt ook klachten die bij COVID-19 passen, maar hij herstelt thuis. Ook hij kan minder goed zaken regelen en vergeet veel.

Vier weken na het verdwijnen van de benauwdheid en hoesten herstellen bij patiënte de smaak en reuk. Ook kan ze zich beter concentreren en zich meer inleven in haar ook ziek geworden partner.
\end{abstract}

gehad lijken na een ic-opname last te hebben van (neuro) psychologische problemen. ${ }^{2}$ Om welke aantallen patiënten het gaat vermeldt het onderzoek niet. Onderzoekers van het Erasmus MC doen een dringende oproep om alle patiënten die COVID-19 hebben gehad na ontslag van de ic-afdeling goed te monitoren op het post intensive care syndrome (PICS). ${ }^{3}$ Bij PICS treden cognitieve problemen op, zoals hinder bij het opnemen en verwerken van informatie. Bovendien zijn er problemen met de werking van het geheugen, het vasthouden van aandacht, de denksnelheid, en met organiseren en plannen. Bij PICS kan er ook sprake zijn van psychische problemen, zoals angst en depressie.

Ook Canadese onderzoekers wijzen op cognitieve en psychische problemen bij patiënten die COVID-19 hebben gehad. ${ }^{4}$ Vermoedelijk tast het virus niet alleen de longen, maar ook de hersenen aan, met neurologische schade als gevolg. ${ }^{5-7}$ Dit lijkt in ieder geval vaker het geval bij patiënten die een ernstige infectie hebben gehad. ${ }^{5}$ De precieze aard, ernst en duur van de neurologische schade van COVID-19 zijn nog niet goed onderzocht. Onder patiënten die op de ic-afdeling waren opgenomen, zien we een toename van cerebrale infarcten. ${ }^{8}$ Bij de longaandoeningen bij COVID-19 lijken cytokines een belangrijke rol te spelen bij het ontstaan van infarcten, waarschijnlijk 


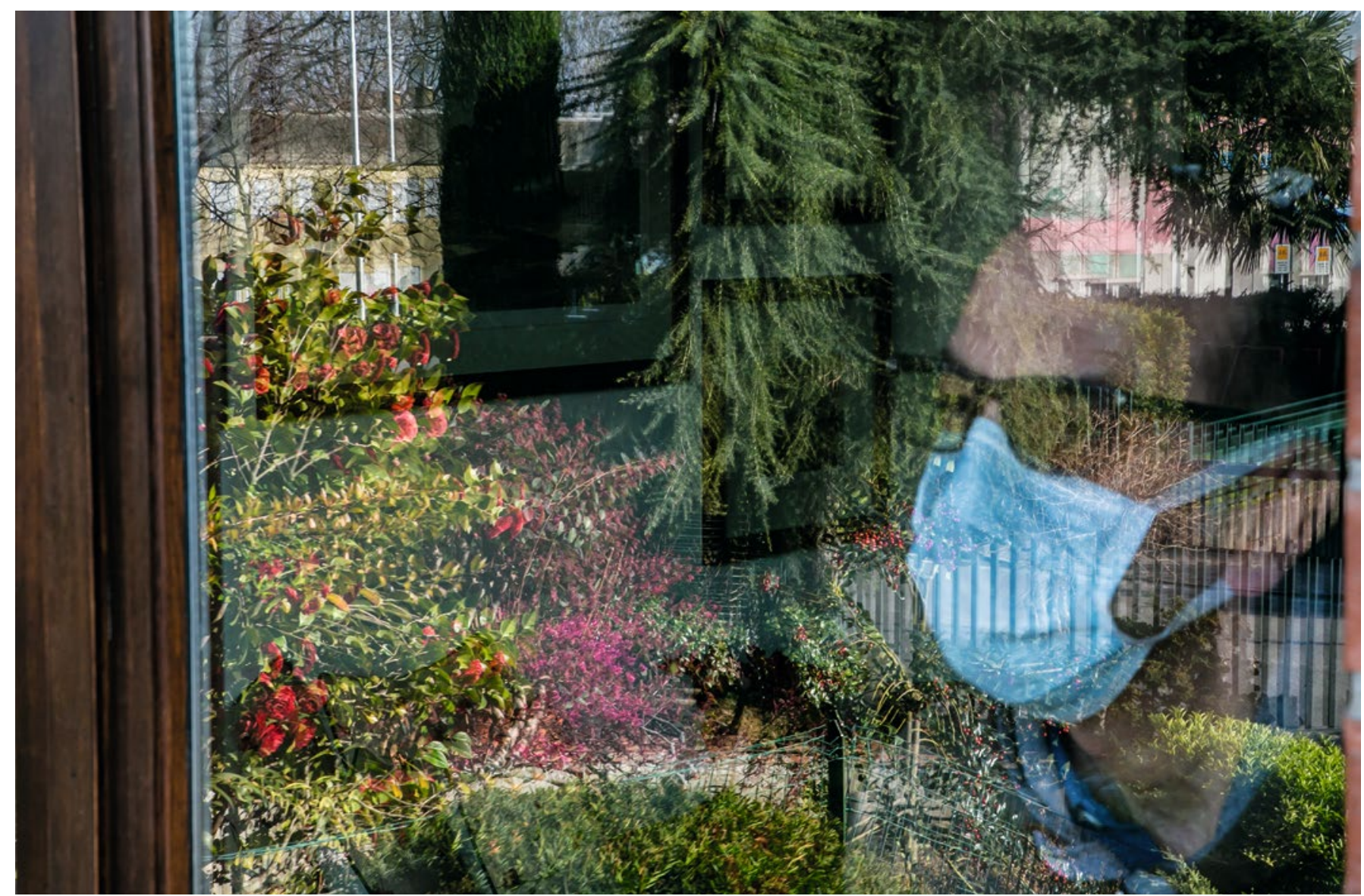

Een doorgemaakte COVID-19-infectie kan gevolgen hebben voor het cognitief functioneren.

Foto: iStock

via de bradykinine-pathway. ${ }^{9}$

Een literatuurreview over de impact op het cognitief functioneren van een andere ernstige longaandoening, het acute respiratory distress syndrome of ARDS, waarvoor patiënten op de ic-afdeling zijn opgenomen, laat zien dat het verminderde cognitieve functioneren tot maanden na ontslag uit het ziekenhuis kan aanhouden..$^{10}$ Niet-aangeboren hersenletsel is een risicofactor voor verder verminderd cognitief functioneren na de aandoening. Andere risicofactoren zijn langdurige blootstelling aan narcosemiddelen en kunstmatige beademing. Ook hypofusie, hypoxemie en demyelinisatie zijn risicofactoren. ${ }^{5}$ Veel Nederlandse COVID-19-patiënten zijn thuis of op een andere afdeling in het ziekenhuis - dus zonder ic-opname hersteld. We vonden geen literatuur over de gevolgen van de aandoening voor hun cognitief functioneren. Deze patiënten hebben per definitie geen last van het PICS. Toch is er ook bij hen mogelijk sprake van verminderd cognitief functioneren nadat zij hersteld zijn verklaard. ${ }^{6,7}$ Dat zagen we ook bij de patiënte uit de casus, die allerlei cognitieve problemen ondervond waarvoor geen andere verklaring voorhanden was. Over de precieze oorzaak van de cognitieve problemen kunnen we slechts speculeren. Zo kan directe schade van de hersenen door het virus en cytokines een rol spelen, maar ook een periode van verminderde saturatie en trombo-embolische processen. ${ }^{8}$ Volgens de Nederlandse Vereniging van Diëtisten valt ook te denken aan schade door minder goede voeding tijdens de ziekteperiode. ${ }^{11}$

(Tijdelijke) cognitieve achteruitgang is vooral risicovol bij mensen met een verstandelijke beperking, omdat zij over beperkte mogelijkheden voor compensatie beschikken. Juist deze groep wordt vaker op jongere leeftijd met het coronavirus besmet, wat mogelijk komt doordat ze beschermd wonen of in instellingen verblijven. ${ }^{12}$ Mensen met een lagere opleiding lijken vaker besmet te worden met het coronavirus en daardoor (ernstig) ziek te worden. ${ }^{12}$ Hieraan kunnen allerlei factoren ten grondslag liggen, zoals een slechtere gezondheid of een risicovolle leefstijl (onder andere vaker roken en overgewicht), maar ook een onwil of onvermogen om de adviezen en maatregelen op te volgen die besmetting moeten voorkomen. Wanneer mensen gedwongen met meer mensen op een kleiner oppervlak wonen, zal het infectierisico groter zijn.

\section{Zorg en begeleiding bij cognitieve problemen}

De Leidraad van de Federatie Medisch Specialisten adviseert om het cognitief functioneren te evalueren. ${ }^{11}$ Ook heeft de Long Alliantie Nederland een handreiking samengesteld met adviezen over behandeling en begeleiding van post-COVID19-patiënten, die aandacht aan dit onderwerp besteedt. ${ }^{13}$ Het Zorginstituut heeft in juli paramedische 'herstelzorg' in de basiszorg beschikbaar gesteld. Deze is bestemd voor mensen die langdurig last hebben van ernstige lichamelijke en cognitieve klachten (zoals geheugenproblemen), moeite hebben met da- 


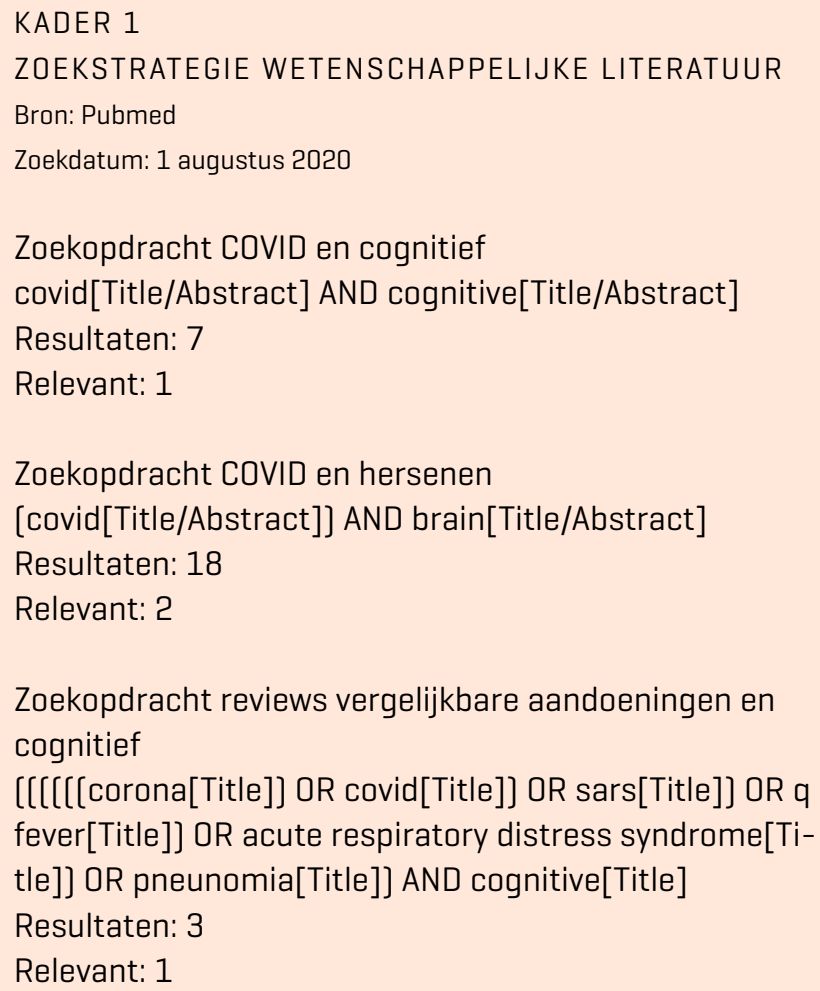

gelijkse activiteiten en moeizaam herstellen. Deze zorg betreft meestal monodisciplinaire of gecombineerde inzet van een fysio- of oefentherapeut, diëtist, ergotherapeut of logopedist. ${ }^{14}$ Voor de huisarts betekent dit dat het goed is om deze patiënten vaker te zien, eventueel conform genoemde de richtlijnen symptomatisch te behandelen en de informatie regelmatig te herhalen omdat het voor deze patiënten lastig blijkt informatie in 1 keer te begrijpen.

\section{CONCLUSIE}

Uit observaties in de huisartsenpraktijk blijkt dat een doorgemaakte COVID-19-infectie gevolgen heeft voor het cognitief functioneren. Dit is mogelijk niet alleen het geval na een ernstige infectie waarbij een ic-opname nodig was of wanneer sprake is van een PICS, maar ook bij patiënten die een 'gewone' ziekenhuisopname hebben gehad of thuis van de ziekte zijn hersteld. We hebben nog geen gegevens over de omvang, aard en prognose bij patiënten die niet in het ziekenhuis opgenomen zijn geweest. Toch willen we huisartsen vragen om op deze klachten te letten en te kijken naar het cognitief functioneren van alle patiënten die een COVID-19-infectie doormaakten. Wat betreft begeleiding zijn vooralsnog alleen adviezen uit de praktijk te geven, die ook in richtlijnen hierover te vinden zijn. Herkennen, erkennen en accepteren zijn daarbij essentieel, zowel voor patiënten als hun omgeving.

\section{LITERATUUR}

1. Eizenga WH, Dautzenberg PLJ, Eekhof JAH, Scholtes ABJ, Van Venrooij MH, Verduijn MM, et al. NHG-Standaard Delier (eerste herziening). Huisarts Wet 2014;57:184-93.

2. Kiekens C, Boldrini P, Andreoli A, Avesani R, Gamna F, Grandi $\mathrm{M}$, et al. Rehabilitation and respiratory management in the acute and early post-acute phase. 'Instant paper from the field' on rehabilitation answers to the COVID-19 emergency. Eur J Phys Rehabil Med 2020;56:323-6.

3. Stam HJ, Stucki G, Bickenbach J. COVID-19 and Post Intensive Care Syndrome: a call for action. J Rehabil Med 2020;52:jrm00044.

4. Simpson R, Robinson L. Rehabilitation following critical illness in people with COVID-19 infection. Am J Phys Med Rehabil 2020;99:470-4.

5. Asadi-Pooya AA, Simani L. Central nervous system manifestations of COVID-19: a systematic review. J Neurol Sci 2020;413:116832.

6. Zhou H, Lu S, Chen J, et al. The landscape of cognitive function in recovered COVID-19 patients. J Psychiatr Res 2020;129:98-102.

7. Das G, Mukherjee N, Ghosh S. Neurological insights of COVID-19 pandemic. ACS Chem Neurosci 2020;11:1206-9.

8. Kloka FA, Kruip MJHA, Van der Meer NJM, Arbous MS, Gommers DAMPJ, Kant KM, et al. Incidence of thrombotic complications in critically ill ICU patients with COVID-19. Thromb Res 2020;191:145-7.

9. Van de Veerdonk F, Netea MG, Van Deuren M, Van der Meer JW, De Mast Q, Bruggemann RJ, et al. Kinins and cytokines in COVID-19: a comprehensive pathophysiological approach. Preprints 2020, 2020040023.

10. Sasannejad C, Ely EW, Lahiri S. Long-term cognitive impairment after acute respiratory distress syndrome: a review of clinical impact and pathophysiological mechanisms. Crit Care 2019;12:352.

11. Federatie Medisch Specialisten. Leidraad Nazorg voor patiënten met COVID-19. Utrecht: Federatie Medisch Specialisten, 2020.

12. Vereniging Gehandicaptenzorg Nederland. Persbericht: Mensen met een verstandelijke beperking vaker op jongere leeftijd besmet met het coronavirus. Utrecht: Vereniging Gehandicaptenzorg Nederland, 2020.

13. Long Alliantie Nederland. Handreiking voor de zorg. Behandeling en begeleiding van post-COVID-19-patiënten: het COVID-19 Associated Syndrome. Amersfoort: Long Alliantie Nederland, 2020.

14. Zorginstituut Nederland. Zorginstituut adviseert tijdelijk ruimere vergoeding paramedische herstelzorg voor patiënten met ernstige COVID-19. Diemen: Zorginstituut Nederland, 2020.

Slockers MT, Magnée T. Cognitieve beperkingen herkennen na COVID-19. Huisarts Wet 2020;63:D0I:10.1007/s12445-020-0843-y. Gezondheidscentrum DWL - Esch, Rotterdam: M. Slockers, huisarts, slockers@hisnet.nl. Onderzoeksinstituut IVO, Den Haag: dr. T. Magnée, onderzoeker. FortaGroep, Capelle: dr. T. Magnée, poh-ggz.

Mogelijke belangenverstrengeling: niets aangegeven. 